\title{
A QUICK CHRONOLOGICAL REVIEW OF THE ELT METHODS ALONG WITH THEIR TECHNIQUES AND PRINCIPLES: CHOOSING ECLECTICISM FROM AMONG LANGUAGE TEACHING METHODS
}

\author{
Turgay Dinçay
}

\begin{abstract}
Teaching a new language either as a second or a foreign language has always been a deep concern for language teachers for centuries. It is for this reason that the human beings have always been in quest of teaching a foreign language more fluently in a shorter time. This quest dates back up to the time when Latin was spoken.

Language teachers have constantly been in an endless discussion about which language teaching method they should use in their classes. Another issue of discussion is if a certain language method is superior to the others.

In order to provide an appropriate answer to the questions above, I have studied the most prominent ELT methods in chronological order along with their key principles and techniques for a better evaluation and assessment of the methods.

In the end of my study, I have chosen eclecticism from among all the methods and suggested that language teachers use the eclectic method, which is a blend of all the methods, and consider their students, the conditions of instructions, and the students' socio-cultural context.
\end{abstract}

Key words: approach, method, technique, principle, context, assessment. 


\title{
YABANCI DİL ÖĞRETIM METODLARININ TEKNIKK VE İLKELERİ İLE BİRLIIKTE KRONOLOJIKK BİR İNCELEMESİ: SEÇMELİ YÖNTEM
}

\author{
$\ddot{O z e t}$ \\ Bir dilin gerek yabancı dil, gerekse ikinci dil olarak ögretilmesi yüzyıllardır öğret- \\ menlerin ilgi alanı olmuştur. Bu nedenledir ki, insanoğlu her zaman yabancı bir dili \\ en kısa zamanda ve en akıcı bir şekilde öğretmenin arayışı içinde olmuştur. Bu \\ arayış Latincenin konuşulduğu döneme kadar uzanır. \\ Öğretmenlerin derslerinde hangi metodu kullanacakları konusundaki tartışmaları \\ bitmez tükenmez bir şekilde devam etmektedir. Diğer bir tartışma konusu ise, her- \\ hangi bir metodun diğerinden üstün olup olmadı̆̆ıdır. \\ Yukarıdaki sorulara yanıt verebilmek ve daha iyi değerlendirme yapabilmek \\ amacıla, en önde gelen metodlar gerek dil ögretim prensipleri ve gerekse \\ teknikleri ile birlikte kronolojik bir akış içinde ele aldım. \\ Çalışmamın son bölümünde, tüm metodların bir karışımı olan seçmeli yöntem \\ üzerinde karar kıldım ve ögretmenlerin bu metodu kullanmalarını ve de dil ögreti- \\ mi esnasında ögrencilerinin ĕgitim ve sosyokültürel ortamlarını her zaman göz \\ önünde bulundurmalarını önerdim. \\ Anahtar sözcükler: yaklaşım, metod, teknik, prensip, yöntem, bă̆lam, değer- \\ lendirme.
}




\section{Introduction}

As everybody agrees, the importance of language learning strategies in foreign language learning and teaching is undeniable. It is for this reason that this paper summarizes the historical background of language learning methods along with the underlying concepts, and outlines the key principles and techniques that are widely used in the classroom. It also considers the teacher's role in the classroom environment for achieving a more effective language teaching.

There has been a serious shift within the field of language learning over the last twenty years. Today the emphasis is on learners and learning rather than teachers and teaching. This paper provides the background of language teaching methods in chronological order, gives various principles presented by several researchers. It also stresses the importance of the teacher's role in strategy training.

In the end of my paper, we tried to answer the question which is most commonly asked by many foreign language teachers, "How does a teacher know which method is best?" and explain why teachers create their own blend which is said to be eclectic. In addition, the factors that teachers need to consider before putting one method into practice are also handled in detail.

My study covers all the ideas and assertions made prior to 2000s since I personally and firmly believe that all the basic ideas of the language teaching methods have almost been written and completed before this period.

\section{A Quick Chronological Review Of The Elt Methods}

In this study on the language teaching methods, all the methods are presented on the basis of the time they were first used as follows:

a. The Grammar-Translation Method

b. The Direct Method

c. The Audio-Lingual Method

d. The Silent Way

e. Desuggestopedia

f. Community Language Learning

g. Total Physical Response

h. Communicative Language Teaching

\subsection{The Grammar- Translation Method}

The Grammar-Translation Method was originally used to teach Latin and Greek (Chastain, 1988,15-27). It was used by language teachers to help students read and 
appreciate foreign language literature. It was believed that students would have a complete command of the grammar of the native language through the study of the grammar of the target language. Thus, this would help them speak and write better in their native language. Finally, it was thought that a) learning a foreign language would help students grow intellectually, and b) the mental exercise of learning would be beneficial although they would probably never use the target language.

This method was later highly criticized for conceiving grammar as an end, not as a means (Demircan,1990,51). The biggest weakness was that the aesthetics of the language was generally ignored due to its negligence of the functional aspects of the language. Senemoğlu $(1997,101)$ and Sönmez $(1993,98)$ also mention the similar major weaknesses and strengths of the Grammar-Translation Method in their books published in the 1900s.

A) Key Principles:

1) Classes are taught in the mother tongue, with little active use of the target language.

2) Much vocabulary is taught in the form of lists of isolated words.

3) Long elaborate explanations of the intricacies of grammar are given.

4) Grammar provides the rules for putting words together, and instruction often focuses on the form and inflection of words.

5) Reading the difficult classical texts is begun early.

6) Little attention is paid to the content of texts, which are treated as exercises in grammatical analysis.

7) Often the only drills are the exercises in translating disconnected sentences from the target language into the mother tongue.

8) Little or no attention is given to pronunciation.

\section{B) Key Techniques:}

Diane Larsen-Freeman, in her book Techniques and Principles in Language Teaching (2000,12-21) provides expanded descriptions of some common / typical techniques closely associated with the Grammar Translation Method:

1) Translation of a Literary Passage

(Translating from target language to native language)

2) Reading Comprehension Questions

(Finding information in a passage, making inferences and relating to personal experience) 
3) Antonyms/Synonyms

(Finding antonyms and synonyms for words or sets of words).

4) Cognates

(Learning spelling/sound patterns that correspond between L1 and the target language)

5) Deductive Application of Rule

(Understanding grammar rules and their exceptions, then applying them to new examples)

6) Fill-in-the-blanks

(Filling in gaps in sentences with new words or items of a particular grammar type).

7) Memorization

(Memorizing vocabulary lists, grammatical rules and grammatical paradigms)

8) Use Words in Sentences

(Students create sentences to illustrate that they know the meaning and the use of new words)

9) Composition

(Students write about a topic using the target language)

\subsection{The Direct Method}

This method came into use when teachers thought that learning how to use a foreign language for the purpose of communication was the goal of instruction. The Direct Method became very popular when the Grammar-Translation Method was not found effective in preparing students to use the target language communicatively. This method generally aims at teaching the language the way we learn our target language. But Kocaman (1983:4) notes that learning a foreign or second language is acquired differently since it takes place after having had the command of the mother tongue. Contrary to the Grammar-Translation Method, no translation is allowed in the classroom. Through the use of visual aids and demonstrations meaning is conveyed in the target language without using the native language. The principles and techniques of this method is listed by Gatenby, E.V. (1958,34-42) as below:

A) Key Principles:

1) Classroom instruction was conducted exclusively in the target language.

2) Only everyday vocabulary and sentences were taught. 
3) Oral communication skills were built up in a carefully traded progression organized around questions-and-answer exchanging between teachers and students in small intensive classes.

4) Grammar was taught inductively.

5) New teaching points were taught through modeling and practice

6) Concrete vocabulary was taught through demonstration, objects, pictures; abstract vocabulary was taught through association of ideas.

7) Both speech and listening comprehension were taught.

8) Correct pronunciation and grammar were emphasized.

B) Key techniques:

1) Lessons begin with a dialogue using a modern conversational style in the target language.

2) Material is first presented orally with actions or pictures.

3) The mother tongue is never used. There is no translation.

4) The preferred type of exercise is a series of questions in the target language based on the dialogue or an anecdotal narrative.

5) Questions are answered in the target language.

6) Grammar is taught inductively_rules are generalized from the practice and experience with the target language.

7) Verbs are used first and systematically conjugated much later after some oral mastery of the target language.

8) Advanced students read literature for comprehension and pleasure.

9) Literary texts are not analyzed grammatically.

10) The culture associated with the target language is also taught inductively.

\subsection{The Audio-Lingual Method}

The Audio-Lingual Method is basically an oral-based approach like the Direct Method. However, it differs from the Direct Method in many respects. First, while the Direct Method emphasizes vocabulary acquisition through exposure to its use in situations, the Audio-Lingual Method drills students in the use of grammatical sentence patterns. Secondly, the Direct Method has a strong theoretical base in linguistics and psychology. Most of the principles of behavioral psychology (Skinner, 1957, 74-81) were incorporated into this method. It is for this reason that the sen- 
tence patterns of the target language are thought to be acquired through conditions which mean to respond correctly to stimuli through shaping and reinforcement. Learners overcome the habits of their native language and form new habits in order to be target language speakers.

The Audio-Visual Method, which is a similar version of this method, has almost the same principles and techniques because dialogue memorization is of great importance (Demircan, 2002, 200). Students watch a movie film, and then the teacher asks them questions by pointing at pictures in the film and gets them to answer the questions. In the final phase of the study, dialogue memorization takes place.

The key principles and techniques of this method associated with the Audio-Lingual Method are summarized below.

A) Key Principles:

1) This method is based on the principles of behavior psychology.

2) It adapted many of the principles and procedures of the Direct Method, in part as a reaction to the lack of speaking skills of the Reading Approach.

3) New material is presented in the form of a dialogue.

4) Based on the principle that language learning is habit formation, the method fosters dependence on mimicry, memorization of set phrases and over-learning.

5) Structures are sequenced and taught one at a time. Structural patterns are taught using repetitive drills.

6) Little or no grammatical explanations are provided; grammar is taught inductively.

7) Skills are sequenced: Listening, speaking, reading and writing are developed in order.

8) Vocabulary is strictly limited and learned in context.

9) Teaching points are determined by contrastive analysis between L1 and L2.

11) There is abundant use of language laboratories, tapes and visual aids.

11) There is an extended pre-reading period at the beginning of the course.

12) Great importance is given to precise native-like pronunciation.

13) Use of the mother tongue by the teacher is permitted, but discouraged among and by the students.

14) Successful responses are reinforced; great care is taken to prevent learner errors.

15) There is a tendency to focus on manipulation of the target language and to disregard content and meaning. 
B) Key Techniques:

1) Make sure that all of the utterances which students will make are actually within the practiced pattern. For example, the use of the AUX verb "have" should not suddenly switch to 'have' as a main verb.

2) Conduct the drills as rapidly as possible so as to insure automaticity and to establish a system.

3) Ignore all but gross errors of pronunciation when drilling for grammar practice.

4) Use the shortcuts to keep the pace of drills at a maximum. Use hand motions, signal cards, notes, etc. to cue response. You are a choir director.

5) Use normal English stress, intonation, and juncture patterns conscientiously.

6) Make sure that the drill material should always be meaningful. If the content words are not known, teach their meanings.

7) Intersperse short periods of drill (about 10 minutes) with very brief alternative activities to avoid fatigue and boredom.

8) Introduce the drill in this way:

a. Focus (by writing on the board, for example)

b. Exemplify (by speaking model sentences)

c. Explain (if a simple grammatical explanation is needed)

d. Drill

9) Don't stand in one place; move about the room standing next to as many different students as possible to spot check their production. Thus you will know who to give more practice to during individual drilling.

10) Use the "backward buildup" technique for long and/or difficult patterns.

-tomorrow

-in the cafeteria tomorrow

— will be eating in the cafeteria tomorrow

- Those boys will be eating in the cafeteria tomorrow.

11) Arrange to present drills in the order of increasing complexity of student response. The question is: How much internal organization or decision making must the student do in order to make a response in this drill. Thus: imitation first, single-slot substitution next, then free response last. 


\subsection{The Silent Way}

One problem with the Audio-Lingual Method that students had difficulty in transferring the habits they had mastered in the classroom to communicative use outside it challenged the idea that learning a language meant forming a set of habits in the early 1960s. Linguist Noam Chomsky $(1964,32)$ proposed that speakers have a knowledge of underlying abstract rules, by which they understand and create novel utterances. Thus, language learning is no longer considered a product of habit formation, but rather of rule formation. Accordingly, acquiring a language is a procedure whereby people use their own thinking process, or cognition, to discover the rules of the language they are learning.

Cognitive Approach (Celce-Murcia, 1991,24-29) appeared as a result of this emphasis on human cognition. In this approach, learners were more actively responsible for their own learning and hypothesizing the formulas in order to discover the rules of the target language. Errors were inevitable and they were signs that learners were actively testing their hypotheses. In the early 1970s Cognitive Approach was of great interest and it was applied to language teaching. Most of the materials contained deductive (students are asked to apply the rules given to them) and inductive (learners themselves discover the rules from the examples and then practice them) grammar exercises. However, no new language method developed from the Cognitive Approach.

The Silent Way developed by Caleb Gattegno (1976, 33-44) shares certain principles of the Cognitive Approach. Therefore, it cannot be said that the Silent Way stemmed directly from the Cognitive Approach. Gattegno believed that learning a language is a process just as babies and young children learn a language. In this process we mobilize our inner resources such as our perception, awareness, cognition, imagination, intuition, creativity, etc. While we learn a language, we integrate anything "new" into ourselves, and use it for further learning.

\section{A) Key Principles:}

This method begins by using a set of colored wooden rods and verbal commands in order to achieve the following:

1) To avoid the use of the vernacular.

2) To create simple linguistic situations that remain under the complete control of the teacher.

3) To pass on to the learners the responsibility for the utterances of the descriptions of the objects shown or the actions performed.

4) To let the teacher concentrate on what the students say and how they are saying it, drawing their attention to the differences in pronunciation and the flow of words. 
5) To generate a serious game-like situation in which the rules are implicitly agreed upon by giving meaning to the gestures of the teacher and his mime.

6) To permit almost from the start a switch from the lone voice of the teacher using the foreign language to a number of voices using it.

7) To provide the support of perception and action to the intellectual guess of what the noises mean, thus bring in the arsenal of the usual criteria of experience already developed and automatic in one's use of the mother tongue.

8) To provide a duration of spontaneous speech upon which the teacher and the students can work to obtain a similarity of melody to the one heard.

\section{B) Key Techniques:}

Larsen-Freeman, in her book Techniques and Principles in Language Teaching (2000) provides expanded descriptions of some common/typical techniques closely associated with the Silent Way. The listing here is in summary form only.

1. Sound-Color Chart - click here to see an example

(The teacher refers students to a color-coded wall chart depicting individual sounds in the target language - students use this to point out and build words with correct pronunciation)

2. Teacher's Silence

(Teacher is generally silent, only giving help when it is absolutely necessary)

3. Peer Correction

(Student are encouraged to help each other in a cooperative and not competitive spirit)

4. Rods

(Rods are used to trigger meaning, and to introduce or actively practice language. They can symbolize whatever words are being taught and be manipulated directly or abstractly to create sentences)

5. Self-correction Gestures

(Teacher uses hands to indicate that something is incorrect or needs changing - e.g. using fingers as words then touching the finger/word that is in need of correction)

6. Word Chart

(Words are depicted on charts, the sounds in each word corresponding in color to the Sound-Color) 
7) Fidel Chart - click here to see an example

(A chart that is color-coded according to the sound-color chart but includes the various English spellings so that they can be directly related to actual sounds)

8. Structured Feedback

(Students are invited to make observations about the day's lesson and what they have learned)

\subsection{Desuggestopedia}

Suggestopedia is a teaching method developed by the Bulgarian psychotherapist Georgi Lozanov. The method has been used in different fields of studies but mostly in the field of foreign language learning. Lozanov claimed that by using this method one can teach languages approximately three to five times as quickly as conventional methods. However, it is not limited to the learning of languages, but language learning was found to be a process in which one can easily measure how much and how fast something is learned.

Lozanov (1978,12-85) asserts that language learning can occur at a much faster rate if we help students remove their psychological barriers to learning which cause their inefficiency. This fear of failure hinders the full use of mental powers that we have. Losanov says that we make use of only five to ten percent of our mental capacity. When the limitations to learning are "desuggested", we can make better use of our reserved capacity. Desuggestopedia which can be defined as the application of the study of suggestion to pedagogy helps students eliminate the feeling that they cannot be successful and, thus, overcome the barriers to learning. In this method the integration of the fine arts stimulates mental reserves and accelerated learning occurs.

A) Key Principles:

1) Learning is facilitated in an environment that is as comfortable as possible, featuring soft cushioned seating and dim lighting.

2) "Peripheral" learning is encouraged through the presence in the learning environment of posters and decorations featuring the target language and various grammatical information.

The teacher assumes a role of complete authority and control in the classroom.

4) Self-perceived and psychological barriers to learners' potential to learn are "desuggested".

5) Students are encouraged to be child-like, take "mental trips with the teacher" and assume new roles and names in the target language in order to become more "suggestible". 
6) Baroque music is played softly in the background to increase mental relaxation and potential to take in and retain new material during the lesson.

7) Students work from lengthy dialogs in the target language, with an accompanying translation into the students' native language.

8) Errors are tolerated, the emphasis being on content and not structure. Grammar and vocabulary are presented and given treatment from the teacher, but not dwelt on.

9) Homework is limited to students re-reading the dialog they are studying - once before they go to sleep at night and once in the morning before they get up.

10) Music, drama and "the Arts" are integrated into the learning process as often as possible.

B) Key Techniques:

Larsen-Freeman, in her book Techniques and Principles in Language Teaching (2000: 84-86) provides expanded descriptions of some common/typical techniques closely associated with Suggestopedia. The listing here is in summary form only.

1) Classroom Set-up

(Emphasis is placed on creating a physical environment that does not "feel" like a normal classroom, and makes the students feel as relaxed and comfortable as possible)

2) Peripheral Learning

(Students can absorb information "effortlessly" when it is perceived as part of the environment, rather than the material "to be attended to")

3) Positive Suggestion

(Teachers appeal to students' consciousness and subconscious in order to better orchestrate the "suggestive" factors involved in the learning situation)

4) Visualization

(Students are asked to close their eyes and visualize scenes and events, to help them relax, facilitate positive suggestion and encourage creativity from the students)

5) Choose a New Identity

(Students select a target language name and/or occupation that puts them "inside" the language they are learning) 
6) Role-play

(Students pretend temporarily that they are someone else and perform a role using the target language)

7) First Concert

(Teacher does a slow, dramatic reading of the dialog synchronized in intonation with classical music)

8) Second Concert

(Students put aside their scripts and the teacher reads at normal speed according to the content, not the accompanying pre-Classical or Baroque music - this typically ends the class for the day)

9) Primary Activation

(Students "playfully" reread the target language out loud, as individuals or in groups)

10) Secondary Activation

(Students engage in various activities designed to help the students learn the material and use it more spontaneously - activities include singing, dancing, dramatizations and games - communicative intent" and not "form" being the focus)

\subsection{Community Language Learning}

The basic principle of this method is to establish interpersonal relationships between the teacher and students to facilitate learning. The thought is that learning, like living, is a social affair and can come about only from social interaction. The students first establish interpersonal relationships in their native language while the teacher focuses their attention on students' needs.

This methodology is not based on the usual methods by which languages are taught. Rather, the approach is patterned upon counseling-learning techniques developed by Charles A. Curran (1977,9-19) and adapted to the peculiar anxiety and threat as well as the personal and language problems a person encounters in the learning of foreign languages. Consequently, the learner is not thought of as a student but as a client. The native instructors of the language are not considered teachers but, rather are trained in counseling skills adapted to their roles as language counselors.

The language-counseling relationship begins with the client's linguistic confusion and conflict. The aim of the language counselor's skill is first to communicate an empathy for the client's threatened inadequate state and to aid him linguistically. 
Then slowly the teacher-counselor strives to enable him to arrive at his own increasingly independent language adequacy. This process is furthered by the language counselor's ability to establish a warm, understanding, and accepting relationship, thus becoming an "other-language self" for the client. The process involves five stages of adaptation:

\section{A) Key Principles:}

There are five important principles in Community Language Learning. These principles are:

1) Language is a behavior of a learner that is directed toward others. The learner can talk about things that make him interested and things that he has been experienced before.

2) A learner can learn a new behavior fast if he is not interrupted. Therefore, a learner as the client must have as many opportunities as possible to practice his language knowledge without much interference from the teacher as counselor.

3) The counselor should give assistance the clients in using their language all the time.

4) The counselor should give assistance in maintaining useful behavior by using three suggested techniques which are (1) give the chance to clients to talk much, (2) develop the language productivity of the clients and (3) give the counseling and then make some evaluations.

5) In preparing the materials, the counselor should choose the easy ones for both the clients and counselor which are suitable for the level and goal to be accomplished.

\section{B) Key Techniques:}

1) The teacher reads a story to the class. The class follows along with their own copies.

2) The teacher brings the class together in a circle.

3) The teacher chooses a student and stands behind him or her.

4) The teacher starts the activity by asking, who is the primary character in the story?

5) The student makes a statement about the story in English by answering the question.

6) The teacher repeats the statement the student made in English. 
7) The student repeats the statement in English, while the teacher records it, either on audio or video cassette.

8) The teacher moves on to the next student, who is asked to respond to the story.

9) After all the students have had a turn at speaking, the teacher and students listen to the tape together and make a list of new vocabulary the students learned in English.

10) Students take home both the tape and the written vocabulary from the board.

\subsection{Total Physical Response}

Total Physical Response is a language learning method based on the coordination of speech and action. It was developed by James Asher, a professor of psychology at San Jose State University, California. It is linked to the trace theory of memory, which holds that the more often or intensively a memory connection is traced, the stronger the memory will be.

James J. Asher $(1996,18)$ defines the Total Physical Response (TPR) method as one that combines information and skills through the use of the kinesthetic sensory system. This combination of skills allows the student to assimilate information and skills at a rapid rate. As a result, this success leads to a high degree of motivation. The basic tenet is understanding the spoken language before developing the skills of speaking. Imperatives are the main structures to transfer or communicate information. The student is not forced to speak, but is allowed an individual readiness period and allowed to spontaneously begin to speak when the student feels comfortable and confident in understanding and producing the utterances.

A) Key Principles:

1) Meaning in the target language can often be conveyed through actions. Memory is activated through learner response. The target language should be presented in chunks, not just word by word.

2) The students' understanding of the target language should be developed before speaking.

3) Students can initially learn one part of the language rapidly by moving their bodies.

4) The imperative is a powerful linguistic device through which the student can direct student behavior.

5) Student can learn through observing actions as well as by performing the actions themselves.

6) It is very important that students feel successful. 
7) Students should not be made to memorize fixed routines.

8) Correction should be carried out in an unobtrusive manner.

9) Students must develop flexibility in understanding novel combinations of target language chunks.

10) Language learning is more effective when it is fun.

11) Spoken language should be emphasized over written language.

12) Students will begin to speak when they are ready.

13) Students are expected to make errors when they first begin speaking. Teachers should be tolerant of them. Work on the fine details of the language should be postponed until students have become proficient.

B) Key Techniques:

1) The teacher says the commands as he himself performs the action.

2) The teacher says the command as both the teacher and the students then perform the action.

3) The teacher says the command but only students perform the action

4) The teacher tells one student at a time to do commands

5) The roles of teacher and student are reversed. Students give commands to teacher and to other students.

6) The teacher and student allow for command expansion or produces new sentences

\subsection{Communicative Language Teaching}

As an extension of the notional-functional syllabus, CLT also places great emphasis on helping students use the target language in a variety of contexts and places great emphasis on learning four language skills - listening, speaking, reading, writing. As Vardar $(1998,15)$ writes in his book on the basic conceptions of linguistics, language is a means of communication and therefore it should be handled as a social phenomenon. In this context, Demirel $(1990,31)$ says that teaching these four skills simultaneously is of great importance since each one of them is integrative of the of the other skills. Its primary focus is on helping learners create meaning rather than helping them develop perfectly grammatical structures or acquire native-like pronunciation. This means that successfully learning a foreign language is assessed in terms of how well learners have developed their communicative competence, 
which can loosely be defined as their ability to apply knowledge of both formal and sociolinguistic aspects of a language with adequate proficiency to communicate.

Students may know the rules of linguistic usage, but be unable to use the language. It became clear that communication required that students perform certain functions as well, such as promising, inviting, and declining invitations within a social context (Wilkins, 1976,32). In short, being able to communicate required more than linguistic competence; it required communicative competence (Hymes, 1971,45-49) knowing when and how to say what to whom. Such observations contributed to a shift in the late 1970s and early 1980s from a linguistic structure-centered approach to a Communicative Approach (Widdowson, 1990,54-61).

CLT is usually characterized as a broad approach to teaching, rather than as a teaching method with a clearly defined set of classroom practices. As such, it is most often defined as a list of general principles or features.

1) An emphasis on learning to communicate through interaction in the target language.

2) The introduction of authentic texts into the learning situation.

3) The provision of opportunities for learners to focus, not only on language but also on the learning management process.

4) An enhancement of the learner's own personal experiences as important contributing elements to classroom learning.

5) An attempt to link classroom language learning with language activities outside the classroom.

A) Key Principles:

1) Presentation of a situation or context through a brief dialogue or several minidialogues, preceded by a motivational activity relating the dialogue to learners' experiences and interest. This includes a discussion of the function and situation: People, roles, setting, topic and the level of formality or informality the function and situation demand.

2) Brainstorming or discussion to establish the vocabulary and expressions to be used to accomplish the communicative intent. Includes a framework or means of structuring a conversation or exchange to achieve the purpose of the speakers.

3) Questions and answers based on the dialogue topic and situation: Inverted, whquestions, yes/no, either/or and open-ended questions.

4) Study of the basic communicative expressions in the dialogue or one of the structures that exemplifies the function, using pictures, real objects, or dramatization to clarify the meaning. 
5) Learner discovery of generalizations or rules underlying the functional expression or structure, with model examples on the chalkboard, underlining the important features, using arrows or referents where feasible.

6) Oral recognition and interpretative activities including oral production proceeding from guided to freer communication activities.

7) Reading and/or copying of the dialogues with variations for reading/writing practice.

8) Oral evaluation of learning with guided use of language and questions/answers, e.g. "How would you ask your friend to ? And how would you ask me to ?"

9) Homework and extension activities such as learners' creation of new dialogues around the same situation.

10) To complete the lesson cycle, provide opportunities to apply the language learned the day before in novel situations for the same or a related purpose.

B) Key Techniques:

1) Authentic Materials:

(Students learn in class, sometimes they can not apply outside world. To overcome this, students, native speakers of the target language users make use of such language in the activities they use the real issues. This update may be a newspaper article. In this first-class weather forecasting, time tables, such as menus or simplifying the subject material can be applied.)

2) Scrambled Sentences:

(Mixed sentences are given a passage to students. This may be a passage before they work. They are asked to put their original sentence in order.)

3) Language Games:

(Games CLT approach often (frequently) is used. Students will find fun games. Three feature a variety of communication activities Morrow's card game is located at: Information gap is because the speaker does not know what to do next week to partner. Speakers will make a choice on how these preferences (which form) will be selected. Speaker of the members of the group receives feedback. If anyone in the group guess the answer will not incomprehensible.)

4) Picture Strip Story:

(Many activities can be done with picture-card stories. Students are given one of the cards and student cards to friends of the first shows. What it will look like 
the second picture of them asks. Where the "information gap" is because students in the group do not know the contents of the picture. What will happen and how the estimates elect. Then, the picture on students, with the official estimates by comparing estimates of the form but will receive feedback from the content.)

5) Role Play:

(There are activities in the role Desuggestopedia approach. CLT is important because students in the way the roles that the different social roles in different social content is given the opportunity. Role in two types of activity can be arranged. Very Structured: Teachers tell students what to say and who they are. Less Structured: Teachers who are students, the state, saying they would talk about what is going to say but what the student chooses. Students are given opportunities to choose. Role activities also "information gaps and feedback" provides.)

\section{Choosing From Among Language Teaching Methods: Eclecticism}

The question which is most commonly asked by many foreign language teachers is, "How does a teacher know which method is best?" After all, while many of the articles presented in this article have certain characteristics in common, there are also some fundamental differences among them. And so in the end, one has to make a choice.

While it is very easy to choose among the methods, some may find it to be very difficult. If a particular method fits with the values, experience, and basic teaching and learning views of a teacher, it is appropriate to his/her students and context. Such teachers who claim one method to be best for them are in favour of absolutism since it is the teacher who has been trained in it and the method chosen is consonant with the teacher's thinking.

Before a teacher puts one method into practice, he always needs to consider his/her students, the conditions of instructions, and the broader sociocultural context. Because a particular method cannot always be a prescription for success for everyone. One method that works well with a certain group of students may not be suitable for some others. It is for this reason that some argue there is no right method for everyone. The most important thing that each teacher should always bear in mind is that each method has its own strengths and weaknesses and that learners are so versatile and can learn well sometimes despite a given method in a given context.

Some teachers believe that there is some value to each method and they are against adopting or rejecting methods in their entirety as being suitable or unsuitable for a 
particular context. Instead, different methods, or parts of methods, may be practiced in different contexts (Prabhu, 1990,22-29).

The teachers who subscribe to the view mentioned in the preceding paragraph pick and choose from among methods to create their own blend which is said to be eclectic. Thus, they are creating their own method by blending aspects of others in a principled manner. Because teaching is full of contingencies and it is also true that there is often a gap between our intentions and our actions and that many decisions are outside the control of teachers. In this context, Fanselow $(1987,11)$ says, "If learning equals one hundred percent, and lack of learning means anything less than one hundred percent, the two percent we are responsible for makes the difference between learning and not learning". For instance, they must teach for a test. Or they may have a class where students come with negative attitudes toward the study of language.

In brief, in the light of the views above, eclecticism can be said to be the best solution to meet the various needs of the students.

\section{Conclusion}

Teachers always need to try new practices in order to continually search for or devise the best method for who they are, who their students are, and the conditions and context of their teaching.

Language teaching methods can be categorized as either Indirect Methods or Direct Methods. Indirect methods are commonly used in assessing reading, listening, vocabulary or grammar and these methods work well especially in large classes. Direct methods are, on the other hand, used in assessing productive skills such as writing or speaking and provides a better picture of what students can do with the languages.

To give an example, using the Grammar Method which can be said to be an Indirect Method is easy for the teacher, but as an approach it is too intellectual for the average pupil on the grounds that it may kill off his/her enthusiasm for language learning. In addition to this, students do not have much chance to practice spoken language. One important benefit of this method for students is that they really gain a good command of grammatical rules that they have previously learned in the classroom.

It is for this reason that some teachers try to veer away from pure Indirect Methods, assuming that they reduce the intellectual content of the lessons and give students little opportunity to speak the language being mastered.

But when a Direct Method is adopted by the teacher, students get the opportunity of thinking in the language practice it by using the productive skills. 
It is also true that a second language learner needs to have not only some knowledge of the grammatical structures of the target language but also oral proficiency.

Eclectic method lies somewhere between the two poles, i.e. Indirect Methods or Direct Methods since it has the following principles in practice:

1. It is simple for both teacher and learner, and is within the capabilities of all teachers. Also, the teacher feels that pupils are progressing satisfactorily.

2. It brings about a balance between the spoken and written or printed word and is flexible enough for the teacher to concentrate on the area(s) he wants.

3. It overcomes the conflict between fluency and accuracy.

4. It increases the rate and amount of learning which takes place in the classroom.

5. Testing is part of the method, and not a separate entity.

6. Constant revision is part of the method.

7. It enables the teacher to set defined limits and has control over oral responses.

8. It reflects the linguistic habits the child has already acquired by learning his/her mother tongue and their ability to assimilate a new language.

9. It offers a new approach to the application of translation work.

10. It gives the pupils a stimulus to say something in the first instance - and it finds ways of supplying the pupils constantly with ideas which they can use for their expression in the foreign language.

11. It enables work done with the teaching aids (e.g. audio-visual aids, computer) to be an extension of the method used in class.

12. It gives the teacher an opportunity to speed up intercommunication between himself/herself and individual pupils.

13. It is sufficiently flexible to cope with various class conditions (as far as pupils' specific / general interests are concerned ).

14. It ensures that pupils are given the opportunity of having the greatest number of meaningful contacts possible both with and in the foreign language - The most important criteria for the validity of any modern method.

In brief, we have confronted the diversity of methods in this study and become aware that there has always been a close link between thought and action. In other terms, thought leads to actions in your teaching. Therefore, teachers are often advised to identify,question, and reaffirm the values of their students before creating their own methods. Teaching is not only thinking and holding certain values; it is also action. Before we start experimenting with a new method, it is always much 
better to try it, observe the consequences, make adjustments, and then try it again. As a final step, it is now time to create your own eclectic method and put it into practice.

\section{Bibliography}

Asher, James. (1996). Learning another language through actions: the complete teacher's guidebook. (5th edn.). Los Gatos, CA: Sky Oaks Productions.

Celce-Murcia, Marianne. (1991). Language teaching approaches: an overview. In Celce-, Murcia, M. (ed.), Teaching english as a second or foreign language. (2nd edn.). Boston, MA: Heinle \& Heinle.

Chastain, Kenneth. (1988). Developing second language skills.San Diego, CA: Harcourt Brace Jovanovich.

Chomsky, Noam. 81964). Current issues in linguistic theory. The Hague: Mouton.

Curran, Charles A. (1977). Counseling-Learning in Second Languages. Cliffside Park, NJ: Counseling-Learning Institutes.

Demircan, Ömer. (1990). Yabancı dil öğretim yöntemleri. İstanbul, Ekin Yayınları.

Demircan, Ömer. (2002). Yabancı dil öğretimleri. İstanbul, DER Yayınları.

Demirel, Özcan. (1990). Yabancı dil ögretimi: Illkeler, yöntemler,teknikler. Ankara: Usem Yayınlar1

Fanselow, John. (1987). Breaking rules: Generating and exploring alternatives in language teaching. New York: Longman.

Gatenby, E.V. (1958). A direct method english course. (3rd edn.). London: Longman.

Gattegno, Caleb. (1976). The common sense of teaching foreign languages. New York: Educational Solutions.

Hymes, Dell. (1971). Competence and performance in linguistic theory. In R.Huxley and E. Ingram (eds.). Language acquisition: Models and methods: London: Academic Press.

Kocaman, Ahmet. (1983). Dil öğrenimi. Türk Dili Dergisi Özel Saylsı. Sayı:379.

Larsen-Freeman, Diane. (2000). Techniques and principles in language teaching: Oxford: Oxford University Press.

Lozanov, Georgi. (1978). Suggestology and outlines of suggestopedy. Philadelphia, PA: Gordon and Breach. 
Prabhu, N.S. 1990. The dynamics of the language lesson. TESOL 26/2: 225-41.

Senemoğlu, Nuray. (1997). Gelişim, ögrrenme ve ögretim: Kuramdan uygulamaya. Ankara, Spot Matbaacilik.

Skinner, B. F. (1957). Verbal behavior. New York: Appleton-Century-Crofts.

Sönmez, Veysel. (1993). Eğitim felsefesi. Ankara, Adım Yayınları

Widdowson, H. G. (1990). Aspects of language teaching. Oxford: Oxford University Press. Wilkins, David A. (1976). Notional syllabuses. Oxford: Oxford University Press.

Vardar, Berke. (1998). Dilbilimin temel kavramları ve ilkeleri. İstanbul, Multilingual Yayınlar1. 